\title{
Reproductive cycle of Bolinus brandaris (Gastropoda: Muricidae) in the Ria Formosa lagoon (southern Portugal)
}

\author{
Paulo Vasconcelos ${ }^{1,2, *}$, Paula Moura ${ }^{1}$, Carlos M. Barroso ${ }^{2}$, Miguel B. Gaspar ${ }^{1}$ \\ ${ }^{1}$ Instituto Nacional de Recursos Biológicos (INRB, I.P./IPIMAR), Avenida 5 de Outubro s/n, 8700-305 Olhão, Portugal \\ ${ }^{2}$ Centro de Estudos do Ambiente e do Mar (CESAM), Departamento de Biologia, Universidade de Aveiro, \\ Campus de Santiago, 3810-193 Aveiro, Portugal
}

\begin{abstract}
The purple dye murex Bolinus brandaris is a commercially valuable gastropod in Portugal. However, there is a lack of knowledge on the reproductive cycle in Atlantic populations of this species. In this context, the reproductive cycle of $B$. brandaris from the Ria Formosa lagoon, southern Portugal, was studied using standard histology and light microscopy and the calculation of bio-physiological indices (gonadosomatic indices for both sexes, penial index for males and capsule gland indices for females). Monthly variation in gonad developmental stages and biophysiological indices revealed that $B$. brandaris has an annual reproductive cycle, long gonadal activity and a relatively short resting phase. Spawning occurred mainly between May and July, with a clear spawning peak from June to July. Gonad maturation and spawning appear to be synchronised with the seasonal variation in seawater temperature. Slight asynchrony between the peak of male gamete release and the peak of female spawning might be interpreted as a modality to increase the reproductive success. The timing of spawning was compared with analogous information available for other regions throughout the species distributional range. The present study provides baseline information for proposing fishery management measures, particularly a closed season in the fishing or harvesting activity during the spawning peak of $B$. brandaris aimed at protecting the female broodstock and collective spawns. The overall results from the bio-physiological indices (especially the penial index and the area-based gonadosomatic and capsule gland indices) encourage the adoption of similar approaches with other gastropod species, namely in routine analyses that do not require a detailed histological description.
\end{abstract}

KEY WORDS: Purple dye murex · Gonad histology · Bio-physiological indices · Gametogenic cycle $\cdot$ Spawning season $\cdot$ Fisheries management

\section{INTRODUCTION}

Marine molluscs are among the most important invertebrate fisheries worldwide (Leiva \& Castilla 2002). The latest statistics available on the world fishery production of miscellaneous marine molluscs report catches around $811 \times 10^{3} \mathrm{t}$ with an estimated value of US\$ 373 million (FAO 2011). Gastropods represent $\sim 2 \%$ of the marine molluscs fished worldwide, and some species have high commercial value in international markets and play important social roles in small-scale fisheries (Leiva \& Castilla 2002). Owing to the rising demand and increasing prices for highly valued species, artisanal fisheries are continuously expanding and strong increases in fishing effort have been observed in many artisanal fisheries around the world (Defeo \& Castilla 2005). In southern Europe, the banded murex Hexaplex trunculus Linnaeus, 1758 and the purple dye murex Bolinus brandaris Linnaeus, 1758 are the main species exploited. 


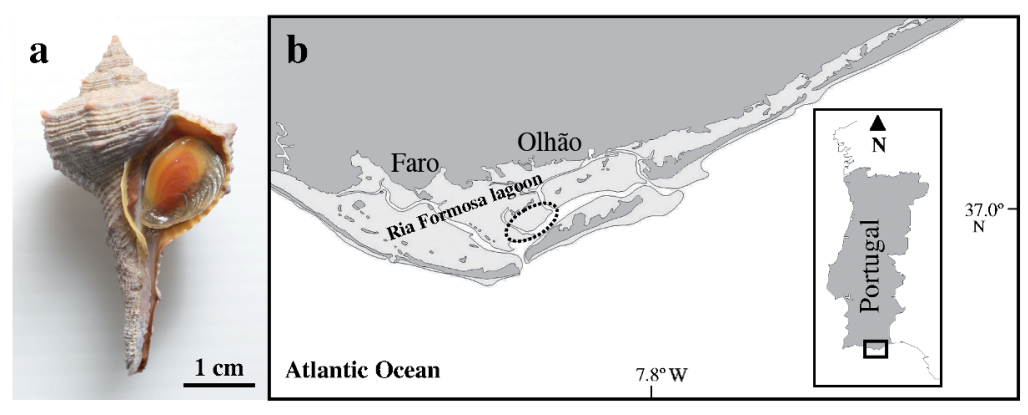

Fig. 1. Bolinus brandaris. (a) Ventral view of live specimen. (b) Dotted oval: sampling area in the Ria Formosa lagoon (Algarve coast, southern Portugal)

Recent literature has highlighted the need for a better understanding of fisheries reproductive biology, both at the individual and population levels (Lowerre-Barbieri et al. 2011). As with other resources, rational decision making and sustainable management of commercially exploited gastropod species require reliable information on key aspects of the target species' biology, including the detailed description of the reproductive cycle. In this context, the present study aimed at describing the reproductive cycle of Bolinus bran-

Both species are harvested in the Mediterranean Sea and in the Atlantic Ocean, especially in Spain (Martín et al. 1995, Anonymous 2001) and Portugal (Vasconcelos et al. 2008a).

Historically, Bolinus brandaris has been a valuable species since the time of the Roman Empire, when it was caught (among other muricid gastropods) for extracting the purple dye (Spanier \& Karmon 1987). Nowadays, B. brandaris is fished for human consumption by using diverse types of artisanal fishing gears (Poppe \& Goto 1991, Houart 2001). This occurs mainly in Spain (Martín et al. 1995, Anonymous 2001, Mallol et al. 2004) and Portugal (Vasconcelos et al. 2008a), but also in France (Bartolome 1985), Italy (Ramón \& Amor 2001, Cecalupo et al. 2006), Greece (Katsanevakis et al. 2011) and occasionally in Turkey and Tunisia (Ramón \& Flos 2001). In Portugal, B. brandaris is fished along the Algarve coast, mainly in the Ria Formosa lagoon, as it is a greatly appreciated seafood with high demand and value in the local seafood markets (reaching prices around 20 to $25 €$ $\mathrm{kg}^{-1}$ for first sale) (Vasconcelos et al. 2008a).

Studies on the purple dye murex are relatively scarce, except in the case of imposex (for details see Vasconcelos et al. 2010 and references therein). Studies on the reproduction of Bolinus brandaris were undertaken mainly with populations from the Mediterranean Sea. These include descriptions of the spawn (Barash \& Zenziper 1980, D'Asaro 1991), morphologic aspects of the male reproductive system (Amor 1988) and female capsule gland (Amor et al. 2007), ultrastructural studies of the oogenesis (Amor et al. 2004), spermatogenesis (Amor \& Durfort 1990a,b, Càceres et al. 1999) and sperm degeneration (Amor et al. 2005). The few studies available on the reproductive cycle of $B$. brandaris were also performed with populations from the Mediterranean Sea, namely in Catalonia (northeastern Spain) (Ramón \& Amor 2002) and Andalucía (southern Spain) (Tirado et al. 2002). daris from the Ria Formosa lagoon, Algarve coast, southern Portugal, based on histological analyses of the gonads and calculation of bio-physiological indices (gonadosomatic indices to assess maturation in both sexes, penial index to determine male copulation and capsule gland indices to assess female spawning). Ultimately, the study aimed at gathering scientifically sound information for proposing management measures to protect and avoid overexploitation of the fishing resource. This could be achieved by implementing a closed season in the fishing or harvesting activity during the spawning season. Additionally, the study also aimed at providing useful information for assessing the potential of $B$. brandaris as a candidate species for molluscan aquaculture.

\section{MATERIALS AND METHODS}

\section{Study area and sampling}

Specimens of Bolinus brandaris (Fig. 1a) were caught by professional fishers in the vicinity of Culatra Island (barrier island of the Ria Formosa lagoon, southern Portugal) (Fig. 1b) with an artisanal fishing gear baited with cockles Cerastoderma edule, locally called a 'wallet-line' (for details see Vasconcelos et al. 2008a). Approximately 40 to 50 individuals (20 for gonad histology and 20 to 30 for the calculation of bio-physiological indices) were sampled monthly during 1 yr (October 2008 to September 2009). During the study period, seawater temperature was monitored daily at the entrance channel of the IPIMAR's Fish Culture Experimental Station, Olhão, which receives water directly from the lagoon.

In the laboratory, individuals were measured for shell length (SL, mm) with a digital calliper (precision 
of $0.01 \mathrm{~mm}$ ) and weighed for total weight (TW, g) on a top-loading digital balance (precision of $0.01 \mathrm{~g}$ ). Shells were cracked in a bench vice to allow removal of the soft parts of the organism (Fig. 2a), which exposed the mantle cavity and allowed observation of the sexual organs. Owing to the occurrence of imposex (superimposition of male sexual characters, penis or vas deferens, onto females) in Bolinus brandaris from the study area (for details see Vasconcelos et al. 2010), females were identified by the presence of a vagina and capsule gland, whereas males were identified by the absence of these organs. The general appearance (size, colour and texture) of the gonads in both sexes, the seminal vesicle (vesicula seminalis) in males, the seminal receptable (receptaculum seminis) and the capsule gland in females were also recorded.

\section{Histology of the gonads}

In Bolinus brandaris, the colour of the gonad is easily distinguishable from the brownish digestive gland (Fig. 2a). However, as in other muricids, the gonad is intimately associated with the underlying digestive gland, which makes it difficult to dissect from the rest of the soma without damage and loss of gonadal tissue. Therefore, this assemblage of tissues (complex: digestive gland plus gonad) was fixed in Davidson's solution for 24 to $48 \mathrm{~h}$ and preserved in $70 \%$ ethanol. Subsequently, a transverse cut ( 2 to $3 \mathrm{~mm}$ thick) was made on the medial zone of the visceral coil (comprising the digestive gland and the gonad), immedi-

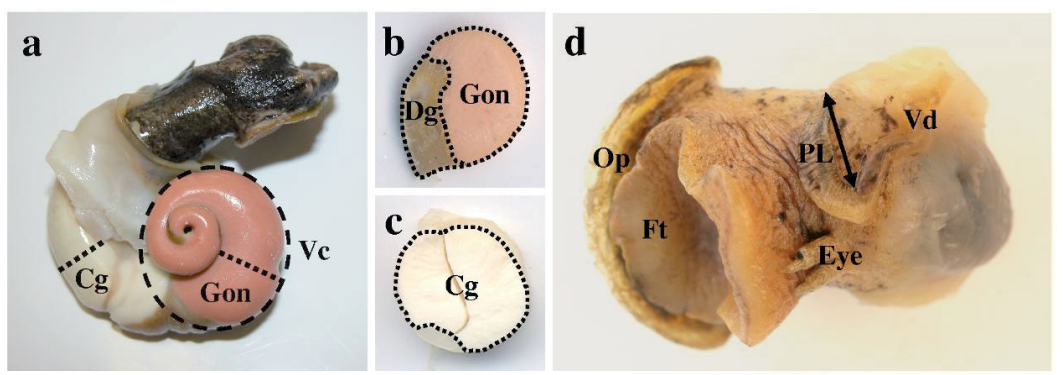

Fig. 2. Bolinus brandaris. Soft parts of the snail and sections for the estimation of the gonadosomatic index $\left(\mathrm{GSI}_{\mathrm{A}}\right)$, capsule gland index $\left(\mathrm{CGI}_{\mathrm{A}}\right)$ and penial index $\left(\mathrm{PI}_{\mathrm{L}}\right)$ : (a) transverse cuts (interrupted lines) made in the medial zones of the visceral coil (complex: digestive gland plus gonad) and of the capsule gland; (b) outlines (dotted lines) traced on the digitized image for measurement of the digestive gland and gonad areas and estimation of the GSI $_{\mathrm{A}^{;}}$(c) outline (dotted line) traced on the digitized image for measurement of the capsule gland area and estimation of the $\mathrm{CGI}_{\mathrm{A}^{i}}(\mathrm{~d})$ location and measurement of the flattened penis for estimation of the $\mathrm{PI}_{\mathrm{L}}$. Cg: capsule gland; Dg: digestive gland; Eye: eyestalks (ocular tentacles); Ft: foot; Gon: gonad; Op: operculum; PL: penis length; Vc: visceral coil; $\mathrm{Vd}$ : vas deferens ately behind the gastric caecum (Fig. 2a). Tissue samples were dehydrated in a graded ethanol series, infiltrated and embedded in paraffin wax. Gonads atoxylin and eosin (H\&E), mounted between a slide and cover slip with synthetic resin and using magnifications of $10 x$ and $40 \times$.

Each month, 10 males (M) and 10 females (F) were selected for histology of the gonads. In order to avoid including sexually immature individuals in the samples, only specimens above the minimum landing size (MLS) legally stipulated for Bolinus brandaris (65 mm SL, based on the size at first sexual maturity) were analysed. In both sexes, gonad maturity stages were classified using a microscopic scale of gonadal development (briefly described in Table 1 and illustrated in Fig. 3), which was successfully employed in a previous study with a sympatric muricid, Hexaplex trunculus (Vasconcelos et al. 2008b). Whenever multiple developmental stages were observed simultaneously within a gonad, the individual was assigned to the prevailing maturity stage.

\section{Bio-physiological indices}

The monthly evolution of the reproductive cycle in both sexes was followed using gonadosomatic indices (GSIs) based on gonad weight and area. In males, a penial index $\left(\mathrm{PI}_{\mathrm{L}}\right)$ based on penis length was employed to ascertain the copulation period. In females, capsule gland indices (CGIs) based on capsule gland weight and area were employed to establish the spawning season. Because of their soft nature, the gonads and the capsule gland are hard to dissect accurately in fresh specimens, which might introduce bias in the weight of both organs. Therefore, after de-shelling the specimens and removing broken shell fragments from the flesh, the soft parts of the organism were preserved in buffered $4 \%$ formaldehyde (in seawater) for at least 24 to $48 \mathrm{~h}$. Prior to dissection of the soft body tissues and reproductive organs, samples were thoroughly washed in running water to remove fixative residues.

For the calculation of the indices based on weight (gonadosomatic index $\left[\mathrm{GSI}_{\mathrm{W}}\right]$ and capsule gland 
Table 1. Bolinus brandaris. Gonad development and microscopic features of each maturity stage

\begin{tabular}{ll} 
Maturity stage & \multicolumn{1}{c}{ Main features of gonadal condition } \\
\hline I. Resting & $\begin{array}{l}\text { Gonads have little internal structure; few, small and incipient primary germ cells (spermatogonia and } \\
\text { oogonia) are dispersed in a large and loose matrix of connective tissue. }\end{array}$ \\
II. Pre-active & $\begin{array}{l}\text { Gonads show some development of acini, embedded in connective tissue; the cytoplasm comprises only a } \\
\text { few spermatocytes and pre-vitellogenic oocytes near the thicker walls. }\end{array}$ \\
& $\begin{array}{l}\text { Gonads progressively increase in size; the connective tissue is condensed in favour of more developed } \\
\text { and closely packed acini; in males, diverse spermatogenic stages are visible (spermatocytes, spermatids }\end{array}$ \\
& $\begin{array}{l}\text { and a few spermatozoa that occur in the lumina of the acini); in females, vitellogenic oocytes proliferate } \\
\text { and appear at the periphery of the acini. }\end{array}$ \\
& $\begin{array}{l}\text { Gonads greatly increase in size; the connective tissue virtually disappears, the acini are more grouped } \\
\text { and highly compressed; in males, the acini are distended and their lumina are full of mature spermatozoa } \\
\text { (although earlier spermatogenic stages still occur near the wall); in females, the lumina of the acini are }\end{array}$ \\
full of mature oocytes with vitellum and packed with yolk granules (although earlier oogenic stages \\
might still occur near the wall). \\
V. Partially \\
Gonads progressively shrink because spawning is in progress; the lumina of the acini become \\
gradually emptier and surrounded by connective tissue; some acini already collapsed and display \\
gametogenic remains; although gametogenesis decreases near the wall, the lumina of most acini still \\
contain mature spermatozoa or oocytes. \\
Gonads greatly reduce in size because most gametes were released; large empty acini with some \\
Gametogenic remains are scattered in loose matrix of connective tissue. Most acini are completely empty, \\
glthough a few might still contain some mature spermatozoa or oocytes; the undischarged oocytes \\
undergo atresia, degenerate and are reabsorbed.
\end{tabular}

index $\left[\mathrm{CGI}_{\mathrm{W}}\right]$ ), the entire soft parts (whole flesh, excluding the operculum) were blot dried with absorbent paper and weighed (SpW). Subsequently, the visceral coil (complex: digestive gland plus gonad) was separated from the rest of the soft parts (foot, mantle and remaining organs) and weighed (VcW). In females, the capsule gland was also dissected and weighed $(\mathrm{CgW})$. Measurements and weighing were made using a digital calliper (precision of $0.01 \mathrm{~mm}$ ) and a top-loading digital balance (precision of $0.01 \mathrm{~g}$ ).

For the calculation of the indices based on area (gonadosomatic index $\left[\mathrm{GSI}_{\mathrm{A}}\right.$ ] and capsule gland index $\left[\mathrm{CGI}_{\mathrm{A}}\right]$ ), the methodology developed in an analogous study with Hexaplex trunculus (Vasconcelos et al. 2008c) was employed. In both sexes, a transverse cut was made in the medial zone of the visceral coil (complex: digestive gland plus gonad, immediately behind the gastric caecum) (Fig. 2a). In females, a transverse cut was also made in the medial zone of the capsule gland (Fig. 2a). In both cases, a section of tissue (2 to $3 \mathrm{~mm}$ thick) was placed on an overhead transparency film and scanned using a previously calibrated scanner (HP Scanjet 5530). Outlines of the digestive gland and gonad (Fig. 2b) and of the capsule gland (Fig. 2c) were traced with a computer 'mouse' and their areas (visceral coil area [VcA], gonad area [GA], capsule gland area [CgA]) were measured using image analysis software (ImageJ v. 1.43). Sub- sequently, the $\mathrm{GSI}_{\mathrm{A}}$ and $\mathrm{CGI}_{\mathrm{A}}$ were estimated as the relative proportion of gonad and capsule gland crosssectional areas in the total cross-sectional area of the visceral coil.

For the calculation of the $\mathrm{PI}_{\mathrm{L}^{\prime}}$ penis measurements were made on fresh specimens without anaesthetisation. Penis measurements were not taken immediately after de-shelling the individuals in order to minimise the contraction of the penis during handling and measurement. The curved penis was partially straightened and its length measured (PL) (Fig. 2d) under a stereo microscope with a graduated eyepiece or using digital callipers, depending on penis size. In male Bolinus brandaris, penis size is proportional to specimen size and penis growth is positively allometric during ontogeny (data not shown). Therefore, to ascertain the monthly variation in PL during the reproductive cycle, a penial index $\left(\mathrm{PI}_{\mathrm{L}}=\mathrm{PL} / \mathrm{SL}\right)$ was employed to eliminate the size-dependence of PL relative to SL. In addition, to minimise the influence of the positive allometry between these variables, the $\mathrm{PI}_{\mathrm{L}}$ was calculated for standard-sized males within a narrow size interval (65 to $75 \mathrm{~mm}$ SL). Moreover, being above the MLS for $B$. brandaris $(65 \mathrm{~mm} \mathrm{SL}$, based on the size at first sexual maturity), this size interval also ensures that only mature males are included in the calculation of the $\mathrm{PI}_{\mathrm{L}}$. This penial index was recently developed and successfully employed in another study with $B$. brandaris from the 


\section{Males}
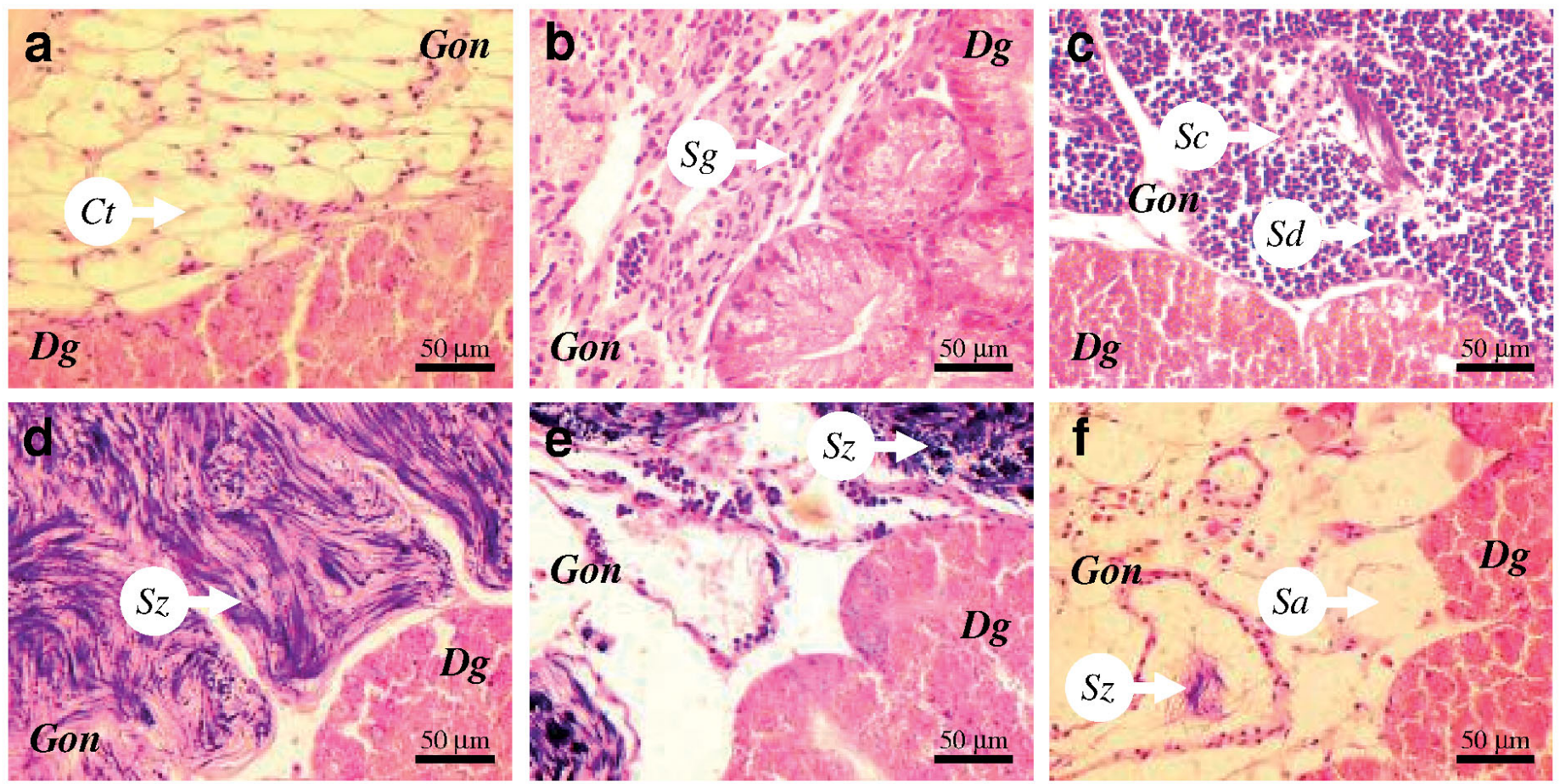

Females
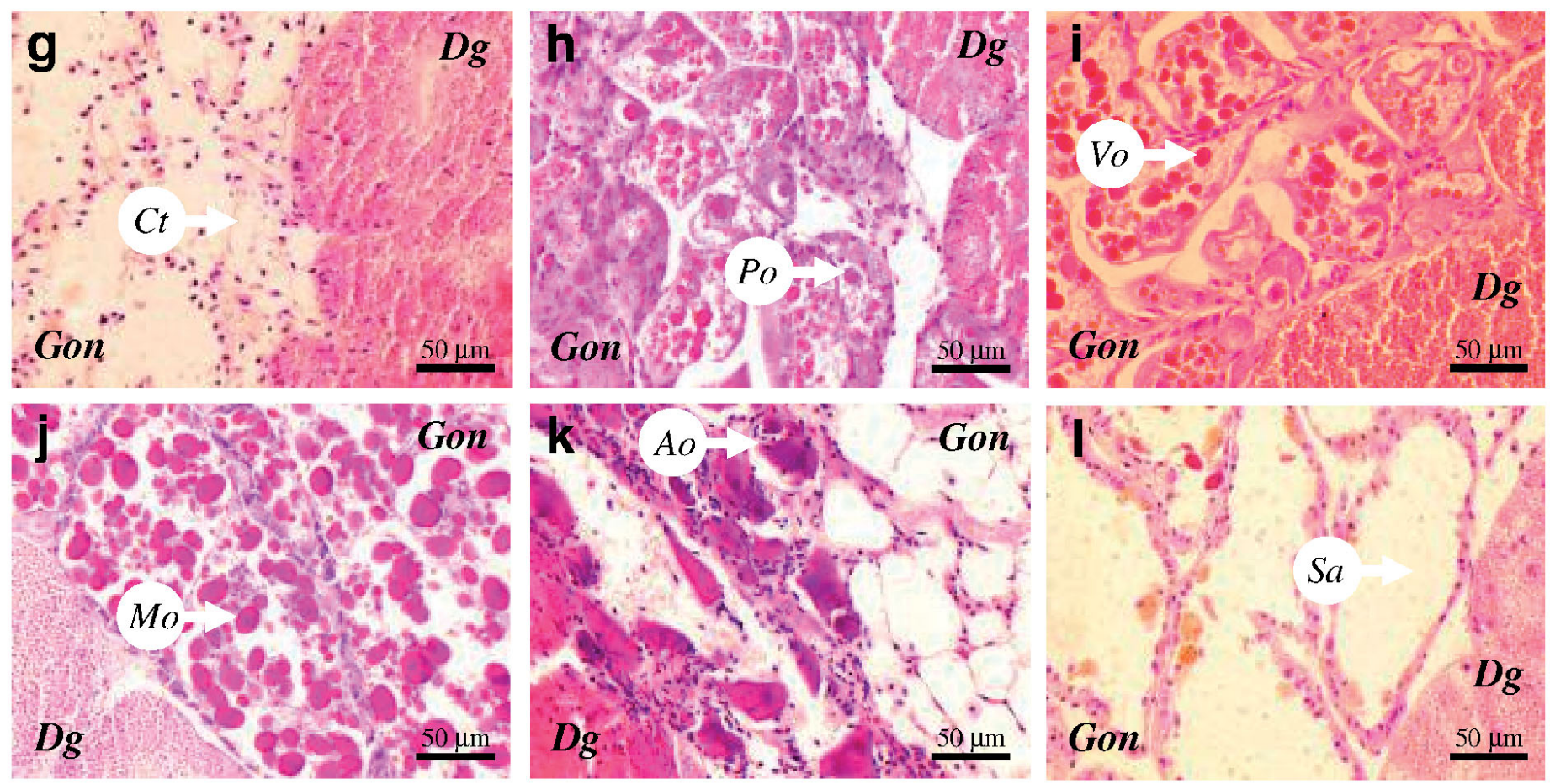

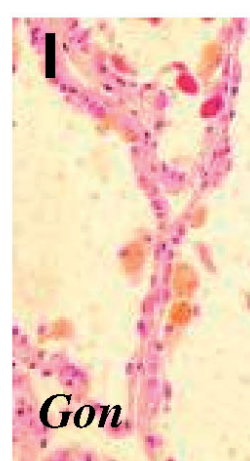

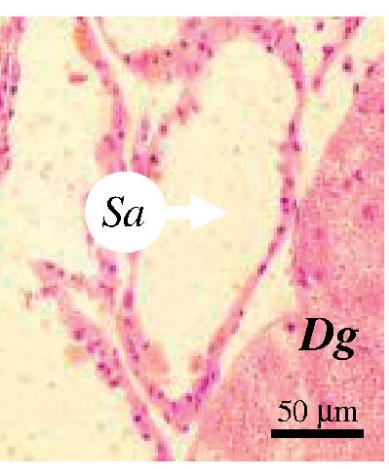

Fig. 3. Bolinus brandaris. Micrographs of histological sections showing the main features of gonadal development at each maturity stage for males (a to f) and females ( $g$ to l). $(\mathrm{a}, \mathrm{g}) \mathrm{I}$ : resting; (b,h) II: pre-active; (c,i) III: active; (d,j) IV: ripe; (e,k) V: partially spent; (f,l) VI: spent (see Table 1). Ao: atresic oocyte; Ct: connective tissue; Dg: digestive gland; Gon: gonad; Mo: mature oocyte; Po: pre-vitellogenic oocyte; Sa: spent acinus; $S c$ : spermatocytes; $S d$ : spermatids; $S g$ : spermatogonia; $S z$ : mature 
Ria Formosa lagoon (for details see Vasconcelos et al. 2011).

Specimens with damaged shells (especially with broken siphonal canal) or ruptured organs (particularly the fragile gonad and capsule gland) were excluded from the analyses. All bio-physiological indices are expressed in percentage (weight, area or length) and were calculated by means of the following equations: $\mathrm{GSI}_{\mathrm{w}}=\mathrm{VcW} / \mathrm{SpW}, \mathrm{GSI}_{\mathrm{A}}=\mathrm{GA} / \mathrm{VcA}$, $\mathrm{CGI}_{\mathrm{w}}=\mathrm{CgW} / \mathrm{SpW}, \mathrm{CGI}_{\mathrm{A}}=\mathrm{CgA} / \mathrm{VcA}, \mathrm{PI}_{\mathrm{L}}=\mathrm{PL} / \mathrm{SL}$.

\section{Statistical analysis}

The sex ratio in the samples, expressed both as percentage of sexes and as number of males per female (F:M), was compared with parity (1:1) using the chi-square test $\left(\chi^{2}\right.$ test). ANOVA were employed to compare specimen size (SL and TW) between sexes and to assess the monthly variations in the biophysiological indices throughout the year. Whenever ANOVA assumptions (normality of data and homogeneity of variances) were not met, ANOVA on ranks (non-parametric Kruskal-Wallis test) was performed. Each time significant differences among groups were detected by the ANOVA or Kruskal-Wallis test, pairwise multiple comparisons were made using Tukey's or Dunn's post hoc tests in order to determine which samples were responsible for the differences. Statistical analyses were performed following Zar (1999) using the software package SigmaStat v. 3.5, with the significance level $\alpha=0.05$.

\section{RESULTS}

\section{Specimen size and sex ratio}

A total of 567 Bolinus brandaris, with broad size and weight ranges (48.6 to $107.7 \mathrm{~mm}$ SL and 4.6 to $79.7 \mathrm{~g}$ TW), were analysed for this study. Mean ( \pm SD) shell length (males: $72.7 \pm 7.4 \mathrm{~mm} \mathrm{SL}$, females: $73.8 \pm$ $8.7 \mathrm{~mm} \mathrm{SL}$ ) and total weight (males: $20.0 \pm 6.2 \mathrm{~g} \mathrm{TW}$, females: $21.1 \pm 8.8 \mathrm{~g}$ TW) were not significantly different between sexes (SL: $H=0.891, \mathrm{p}=0.345$; TW: $H=0.298, \mathrm{p}=0.585)$.

Overall, females $(\mathrm{n}=309)$ predominated over males ( $\mathrm{n}=258$ ), corresponding to a statistically significant unbalanced sex ratio $\left(\mathrm{F}: \mathrm{M}=1.2: 1, \chi^{2}=4.41, \mathrm{p}<\right.$ 0.05). Most monthly samples had parity sex ratio (F:M = 1:1) (Fig. 4a). The few exceptions were the dominance of males in May $\left(\chi^{2}=16.82, \mathrm{p}<0.01\right)$ and the dominance of females in February $\left(\chi^{2}=8.82, \mathrm{p}<\right.$
0.01), April $\left(\chi^{2}=10.58, \mathrm{p}<0.01\right)$ and July $\left(\chi^{2}=5.02\right.$, $\mathrm{p}<0.05$ ) (Fig. 4a). Most size classes presented balanced sex ratios (F:M = 1:1), especially in the smaller and intermediate size classes (except the size class 65-70 mm SL) (Fig. 4b). An increasing proportion of females was evident in the largest size classes, leading to female-biased sex ratios in the size classes 85-90 mm SL $\left(\chi^{2}=4.97, \mathrm{p}<0.05\right)$ and $>90 \mathrm{~mm}$ SL $\left(\chi^{2}=5.79, \mathrm{p}<0.05\right)$ (Fig. $\left.4 \mathrm{~b}\right)$.

\section{Histology of the gonads}

The monthly frequency of Bolinus brandaris at each stage of gonad maturity revealed the simultaneous occurrence of diverse stages of gonadal development almost year-round (Fig. 5). During the whole year, males presented higher frequencies of more advanced maturity stages (active $=23.0 \%$, ripe $=$ $32.7 \%$; Fig. 5a) than did females (active $=17.9 \%$, ripe $=24.1 \%$; Fig. 5b).

Male gonad development started in autumn and continued steadily during winter, as revealed by the increasing monthly proportion of active maturity stages from October to January. Ripe male gonads were first observed in February and their monthly frequency augmented until May (reaching 100\% in April and May). Afterwards, partially spent gonads occurred mainly in June and July, reflecting male gamete release. The highest proportions of spent gonads were registered mostly in August and September, indicative of the beginning of a relatively short resting phase in male reproductive cycle (Fig. 5a).

Female gonad development began slightly later (late winter to early spring), and active gonadal stages were found mostly in February and March. Ripe female gonads were detected in variable proportions from February to July, and the greatest percentages were registered in April (75\%), May (60\%) and June (70\%). Subsequently, partially spent gonads appeared in June and were predominant in July $(70 \%)$, suggesting the main spawning period was occurring. The highest frequencies of spent gonads (together with partially spent gonads) were observed in August and September, signalling the beginning of the period with the lowest reproductive effort (resting phase in female reproductive cycle). Overall, there was a slight asynchrony in the reproductive cycle between sexes, in which males reached maturation earlier and had a slightly shorter resting phase than females. Moreover, the peak of male gamete release occurred $\sim 1$ mo before the peak of female spawning (Fig. 5b). 
Fig. 4. Bolinus brandaris. Sex ratios: (a) monthly variation and (b) variation according to specimen size (grouped into $5 \mathrm{~mm}$ shell length [SL] classes). Interrupted lines represent parity (1:1). Samples with statistically significant unbalanced sex ratio $\left(\chi^{2}\right.$ test $):{ }^{*} \mathrm{p}<0.05,{ }^{* *} \mathrm{p}<0.01$
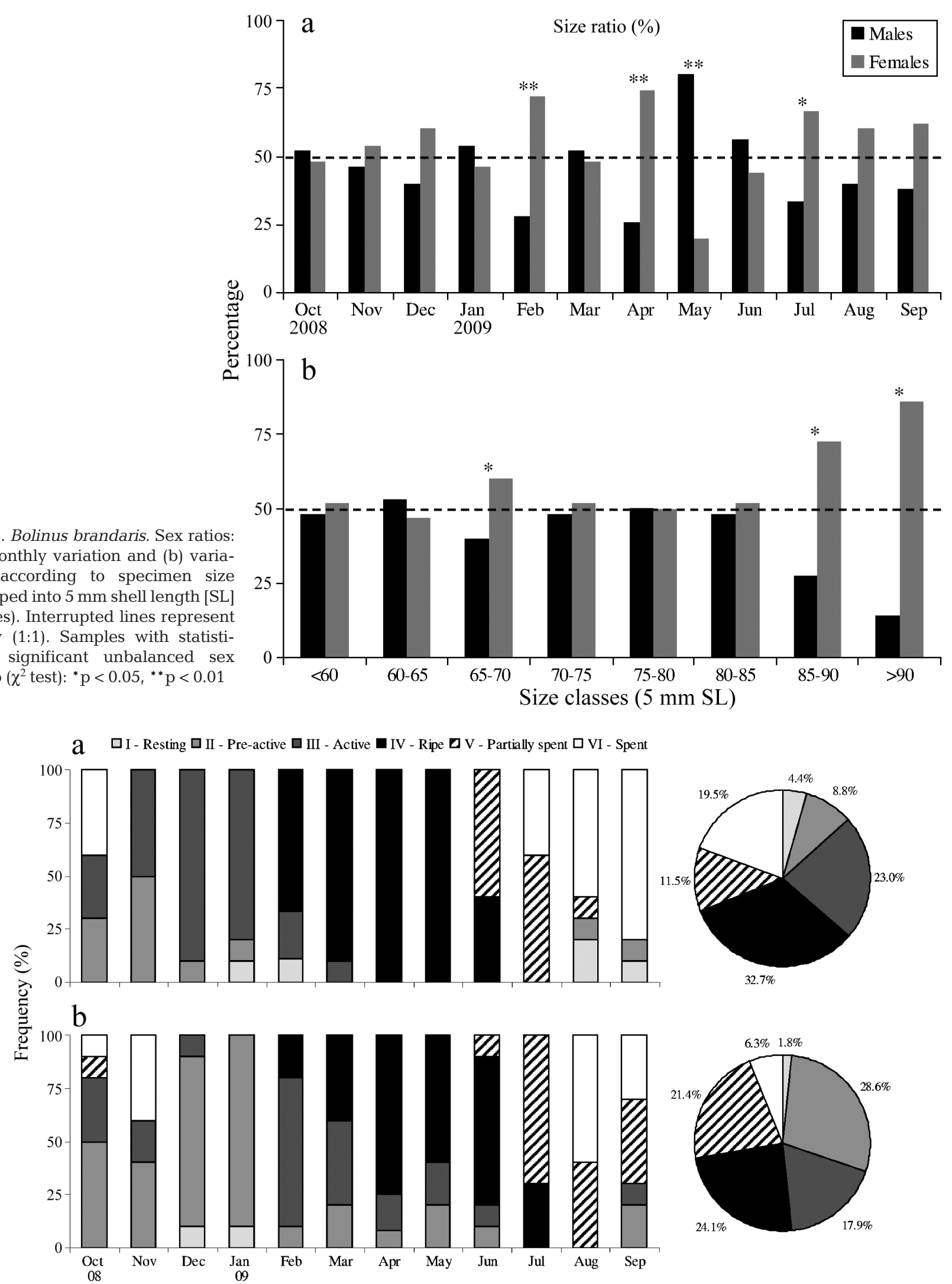

Fig. 5. Bolinus brandaris. Monthly variation and annual frequency of gonad maturity stages I to VI (see Table 1) for (a) males and (b) females 


\section{Bio-physiological indices}

The gonadosomatic indices $\left(\mathrm{GSI}_{\mathrm{W}}\right.$ and $\mathrm{GSI}_{\mathrm{A}}$ ) of Bolinus brandaris (Fig. 6) displayed roughly similar temporal trends and highly significant monthly variations throughout the year, which were less pronounced in GSI $_{\mathrm{W}}$ (Fig. 6a) compared with GSI $_{\mathrm{A}}$ (Fig. 6b). Both indices were significantly higher in males than in females $\left(\mathrm{GSI}_{\mathrm{W}}: H=35.198, \mathrm{p}<0.001\right.$; $\left.\mathrm{GSI}_{\mathrm{A}}: H=44.031, \mathrm{p}<0.001\right)$, reflecting greater reproductive investment by males throughout the year. On the whole, the indices increased more or less steadily in both sexes during winter and early spring, reaching the highest values around April to June, and then decreased sharply between June and July, leading to the lowest values registered during summer (Fig. 6a,b). The increasing trends in $\mathrm{GSI}_{\mathrm{W}}$ and $\mathrm{GSI}_{\mathrm{A}}$ reflect gonad replenishing and were relatively similar between sexes. Nevertheless, there was a slight asynchrony in the maturation peak between sexes
(1 to 2 mo delay), which occurred earlier in males (April to June) than in females (June). In both sexes, the sharp declines in GSI $_{\mathrm{W}}$ and $\mathrm{GSI}_{\mathrm{A}}$ between June and July denote spent gonads and the peak of gamete release, followed by a relatively short resting phase during late summer (starting in AugustSeptember), which was slightly longer and more evident in females than in males (Fig. 6a,b).

The male penial index $\left(\mathrm{PI}_{\mathrm{L}}\right)$ presented a marked seasonal trend throughout the year $(F=7.877, \mathrm{p}<$ 0.001), during which it increased continuously during winter and spring (reaching a peak in May) and then decreased steadily until autumn (lowest $\mathrm{PI}_{\mathrm{L}}$ values registered between September and November) (Fig. 7a). In practice, $\mathrm{PI}_{\mathrm{L}}$ increased during maturation and prior to the breeding season and then decreased until the resting phase in the male reproductive cycle. The highest value observed in May $\left(\mathrm{PI}_{\mathrm{L}}=12.5 \%\right)$ corresponded to the peak of male copulative activity (Fig. 7a). The female capsule gland indices $\left(\mathrm{CGI}_{\mathrm{W}}\right.$ and $\left.\mathrm{CGI}_{\mathrm{A}}\right)$
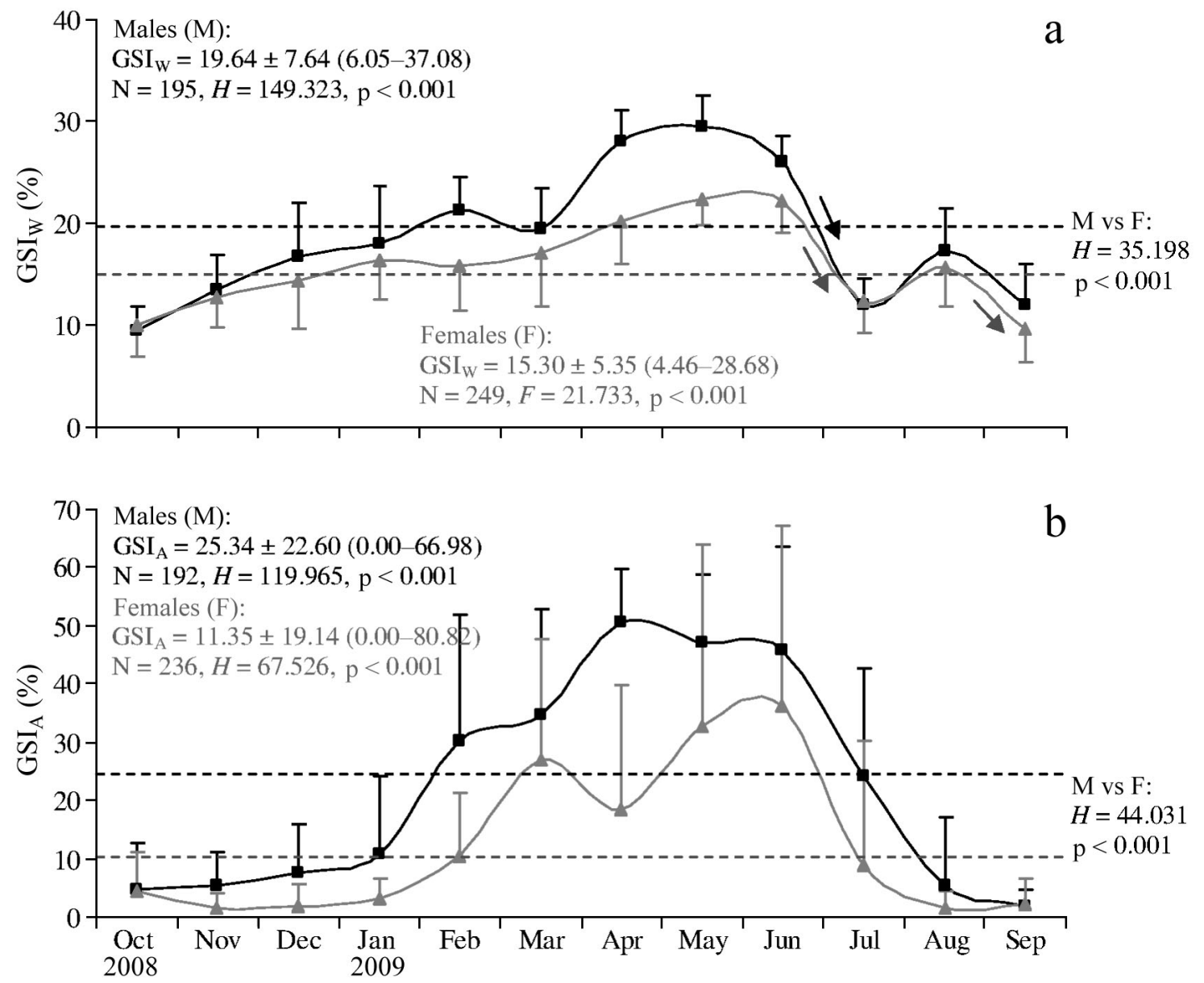

Fig. 6. Bolinus brandaris. Monthly variation in the gonadosomatic indices (means \pm SD): (a) gonadosomatic index based on weight $\left(\mathrm{GSI}_{\mathrm{W}}\right)_{i}(\mathrm{~b})$ gonadosomatic index based on area $\left(\mathrm{GSI}_{\mathrm{A}}\right)$. Interrupted lines: annual mean. Arrows: statistically significant variations between consecutive monthly samples (Tukey's test or Dunn's test, $\mathrm{p}<0.05$ ) 

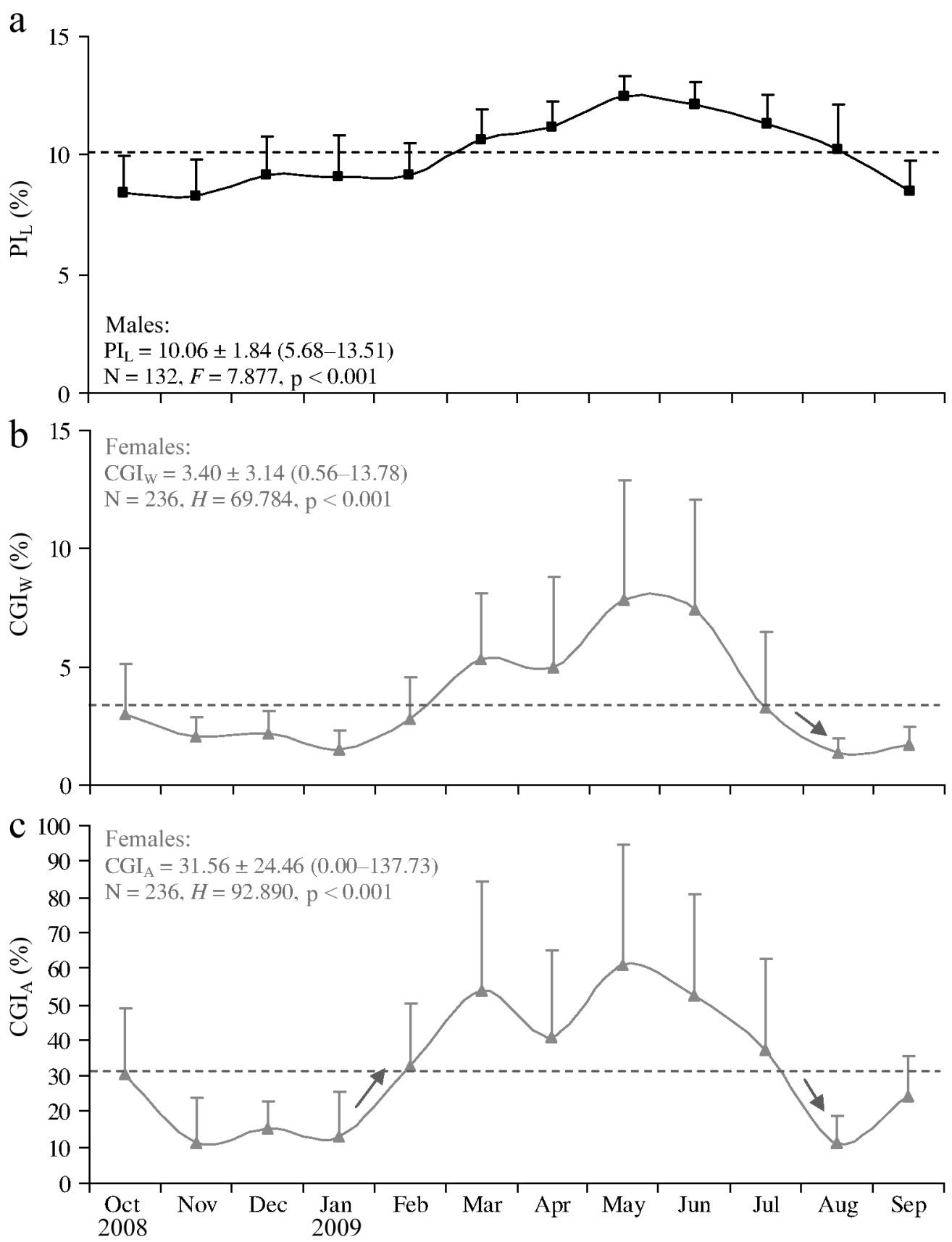

Fig. 7. Bolinus brandaris. Monthly variation in male penial index and female capsule gland indices (means + SD): (a) penial index based on penis length $\left(\mathrm{PI}_{\mathrm{L}}\right)_{i}(\mathrm{~b})$ capsule gland index based on weight $\left(\mathrm{CGI}_{\mathrm{W}}\right)$; (c) capsule gland index based on area $\left(\mathrm{CGI}_{\mathrm{A}}\right)$. Interrupted lines: annual mean. Arrows: statistically significant variations between consecutive monthly samples (Tukey's test or Dunn's test, $\mathrm{p}<0.05)$

also displayed highly significant monthly variations during the reproductive cycle $\left(\mathrm{CGI}_{\mathrm{W}}: H=69.784, \mathrm{p}<\right.$ 0.001 ; $\mathrm{CGI}_{\mathrm{A}}: H=92.890, \mathrm{p}<0.001$ ) (Fig. $7 \mathrm{~b}, \mathrm{c}$ ) and seasonal trends similar to female GSI $_{\mathrm{W}}$ and especially GSI $_{\mathrm{A}}$ (Fig. 6a,b). Both $\mathrm{CGI}_{\mathrm{W}}$ and $\mathrm{CGI}_{\mathrm{A}}$ increased almost continuously from late winter to spring, reaching a peak in May, indicative of replenished capsule glands. Subsequently, sharp and continuous de- creases in $\mathrm{CGI}_{\mathrm{W}}$ and $\mathrm{CGI}_{\mathrm{A}}$ observed from May to August reflected the spawning season of Bolinus brandaris, and a clear spawning peak was evident in June to July. Nevertheless, the slight decreases in $\mathrm{CGI}_{\mathrm{W}}$ and $\mathrm{CGI}_{\mathrm{A}}$ that occurred between March and April (Fig. $7 \mathrm{~b}, \mathrm{c})$, accompanied by a simultaneous small decline in female GSI $_{\mathrm{A}}$ (Fig. 6b), apparently indicated the occurrence of a minor spawning event. 


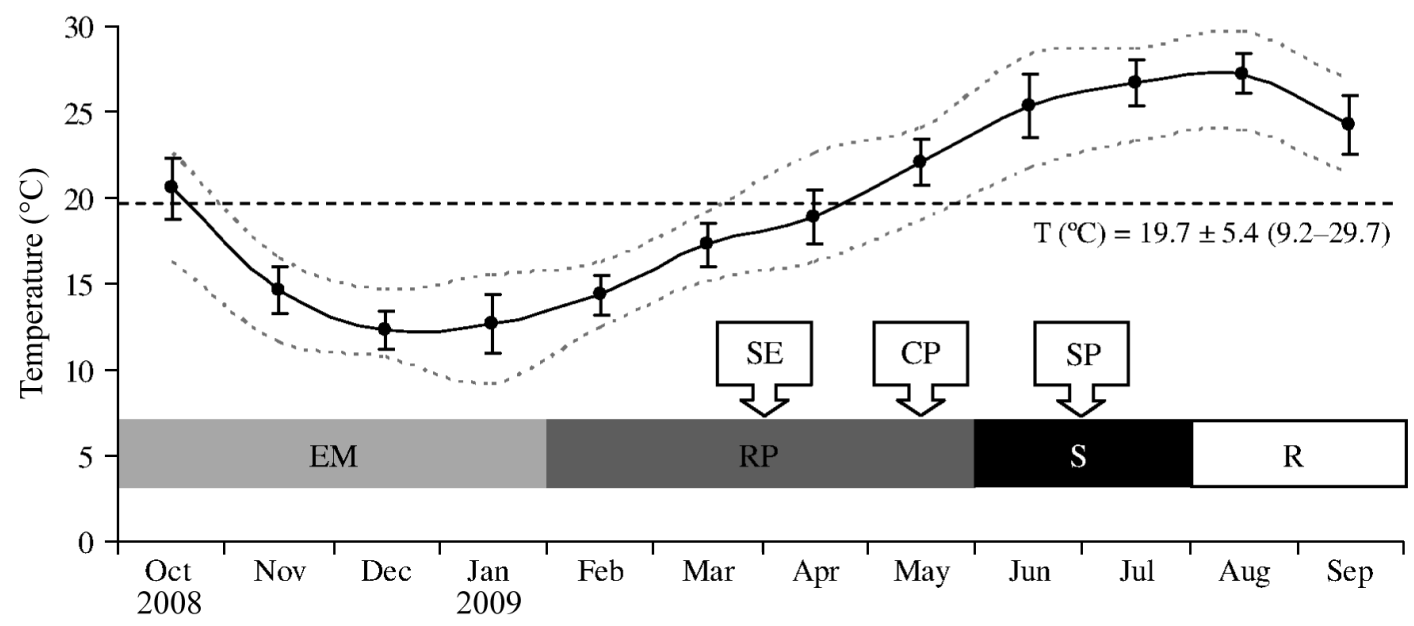

Fig. 8. Bolinus brandaris. Temporal evolution of the reproductive cycle (timing of gonadal maturation, spawning and resting) and monthly variation in seawater temperature (mean $\pm \mathrm{SD}$ ) in the Ria Formosa lagoon. Interrupted lines: annual mean and range (minimum-maximum). EM: early maturation; RP: ripening; S: spawning; R: resting; SE: minor spawning event; CP: copulation peak; SP: spawning peak

\section{Seawater temperature and timing of reproduction}

Annual mean seawater temperature during the whole study period was $19.7 \pm 5.4^{\circ} \mathrm{C}$ and ranged between $12.3 \pm 1.1^{\circ} \mathrm{C}$ in December and $27.2 \pm 1.2^{\circ} \mathrm{C}$ in August (Fig. 8). Lowest and highest temperatures were recorded in January $\left(9.2^{\circ} \mathrm{C}\right)$ and in August $\left(29.7^{\circ} \mathrm{C}\right)$, respectively. During the extended period of gonadal activity, ripening of the gonads was apparently triggered by the rising temperature during spring (particularly evident between March and May, when mean temperature increased almost $5^{\circ} \mathrm{C}$ ). The peak of copulative activity (as signalled by $\mathrm{PI}_{\mathrm{L}}$ ) occurred in May when mean temperature reached $22.1^{\circ} \mathrm{C}$. Although there was slight asynchrony between male gamete release and female spawning, the spawning peak occurred during June and July (as evidenced by GSI and CGI), when the mean temperature reached 25.3 and $26.7^{\circ} \mathrm{C}$, respectively. The short resting phase (slightly longer in females than in males) started simultaneously in both sexes in August and was synchronous with highest mean temperature $\left(27.2^{\circ} \mathrm{C}\right)$ (Fig. 8).

\section{DISCUSSION}

The overall samples of Bolinus brandaris analysed in this study presented a statistically significant unbalanced sex ratio, with predominance of females over males ( $\mathrm{F}: \mathrm{M}=1.2: 1)$. This female-biased sex ratio corroborates previous works with this species along the Catalan coast (Ramón \& Amor 2001, 2002, Mallol et al. 2004), whereas parity sex ratio (1:1) was observed in a study along the Andalusian coast (Tirado et al. 2002). Although most monthly samples had parity sex ratio (1:1), males predominated in May and females predominated in February, April and July. Some of these unbalanced sex ratios may be influenced by the reproductive behaviour of $B$. brandaris: the highest percentage of males $(80.0 \%$ in May) coincided with the peak of copulative activity, as supported by the penial index; the greatest percentages of females occurred both before the breeding period ( $74.0 \%$ in April) and after the spawning peak ( $66.7 \%$ in July), as supported by the gonadosomatic and capsule gland indices. In muricids, conspecific cues appear to be responsible for aggregating spawning females during communal oviposition (e.g. Swanson 2004 and references therein). In fact, $B$. brandaris females form crowded agglomerations to deposit collective spawns (Martín et al. 1995, Mallol et al. 2004, Vasconcelos et al. 2008a) and decrease or even interrupt the feeding activity during the spawning period. In the present study, individuals were caught with a baited fishing gear ('wallet-line') (Vasconcelos et al. 2008a). The behavioural response to prey or bait is expected to differ depending on the sex and developmental stage of the whelks, which are less likely to feed and thus move towards baited traps during periods of increased reproductive activity (e.g. Martel et al. 1986a,b, Himmelman \& Hamel 1993, Ilano et al. 2003, Cudney-Bueno et al. 2008). Altogether, this may explain the unbalanced sex ratios registered during breeding and spawning of $B$. brandaris in the Ria Formosa lagoon. 
Although most size classes presented balanced sex ratios (1:1), the proportion of females increased markedly in largest size classes (85-90 $\mathrm{mm}$ and $>90 \mathrm{~mm}$ SL), generating female-biased sex ratios. This agrees with the general trend in gonochoristic gastropods: females are usually more common in the older fractions of the population (Fretter \& Graham 1994). Female-biased sex ratios among older individuals probably reflect differential growth between sexes (particularly after reaching sexual maturity), and females allocate higher energy expenditure towards growth than reproduction, i.e. females grow faster and reach a larger size than males. The population of Bolinus brandaris from the Catalan coast was also female-biased, but both sexes presented a similar size structure (Ramón \& Amor 2002).

In general, the most relevant features of the reproductive cycle of Bolinus brandaris in the Ria Formosa lagoon were an annual cycle, long period of gonadal activity, relatively short resting phase and slight asynchrony in gonadal development between sexes. Gonad maturation increased gradually during winter and spring, coincident with rising seawater temperature, and ripe gonads were found mainly between April and June. Both the histological analysis of the gonads and the bio-physiological indices detected a clear spawning peak from June to July, followed by a relatively short resting phase in the reproductive cycle of both sexes during late summer (starting in August-September). Accordingly, field observations in the Ria Formosa lagoon confirmed the occurrence of $B$. brandaris collective spawns mostly in June (Vasconcelos et al. 2008a). Information available in the literature reveals a slight variation in the reproductive cycle of $B$. brandaris throughout the distributional range of the species in the Atlantic Ocean and Mediterranean Sea (Table 2). Along Mediterranean coasts, $B$. brandaris apparently has a lengthy spawning season, ranging from spring (Bartolome 1985) to summer (Martín et al. 1995). Nevertheless, most studies mention a spawning season occurring mainly between May and July, namely in May to June (Anonymous 2001, Ramón \& Flos 2001), May to July (Barash \& Zenziper 1980, Tirado et al. 2002, Mallol et al. 2004) and June to July (Ramón \& Amor 2002). The spawning peak is reported to occur in June to July (Ramón \& Amor 2002). In the present study, a minor spawning event apparently took place between March and April. Similarly, a small spawning episode was also detected in April in B. brandaris from Sant Carles de la Ràpita (Catalan coast, western Mediterranean) (Ramón \& Amor 2002).

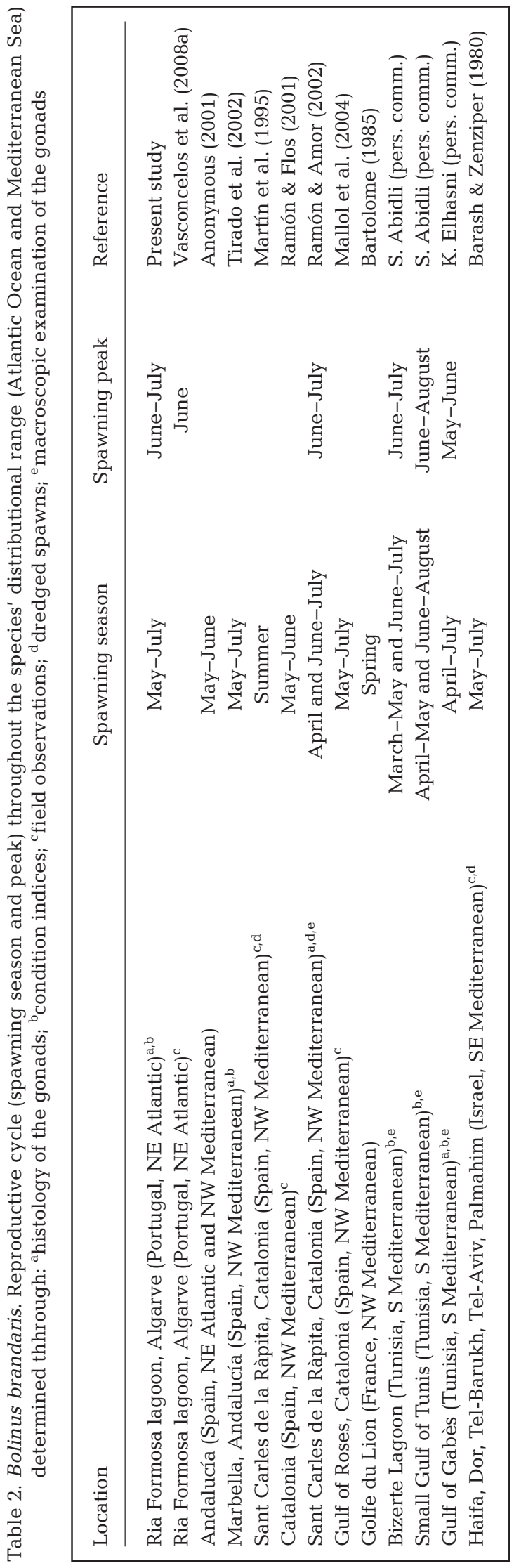


Previous studies on Bolinus brandaris have also reported long periods of gametogenic activity (especially in males) (Ramón \& Amor 2002, Tirado et al. 2002), with consequent short resting phases in the reproductive cycle, mainly in middle summer to middle autumn (Tirado et al. 2002), particularly between August and October (Ramón \& Amor 2002) or between September and November (Mallol et al. 2004). The purple dye murex is a species with internal fecundation; thus, the long period of male gonadal maturity allows increasing the number of copulations (Ramón \& Amor 2002). After copulation, females can store viable sperm in the seminal receptacle (receptaculum seminis) for a long period before oocyte fertilisation by the sperm and spawning take place (Fretter \& Graham 1994). After oocyte fertilisation, the ingestive gland performs the enzymatic digestion and subsequent resorption of non-functional spermatozoa (Amor et al. 2005). This explains the slight asynchrony between the peak of male gamete release and the peak of female spawning, which was also observed in other studies on the reproductive cycle of $B$. brandaris (Ramón \& Amor 2002, Tirado et al. 2002). According to Ramón \& Amor (2002), these differences in the timing of testis and ovary development, and specifically the existence of mature males when females are not ripe, may be interpreted as a modality to increase the reproductive success. Indeed, the storage of viable sperm in the seminal receptacle allows females to produce spawn only when environmental conditions are ideal for the development and survival of encapsulated eggs and embryos.

Reproductive dynamics in gastropods, including the seasonal regulation of gonad development, gametogenesis, breeding and spawning, are controlled by environmental cues that allow reproduction to occur at the most favourable time (Wayne 2001, Harding et al. 2008, Hotchkiss et al. 2008). The seasonal cycle in seawater temperature influences the quantity and quality of available food and regulates metabolic activities. Altogether, seawater temperature and food availability control the precise timing of breeding and spawning and is also responsible for year-to-year variations in the reproductive cycle (Sternberg et al. 2010). In Bolinus brandaris, gonadal ripening and spawning were apparently triggered by the steady increase in seawater temperature during late spring to early summer, when temperature had risen by almost $10^{\circ} \mathrm{C}$ between March $\left(17.3^{\circ} \mathrm{C}\right)$ and July $\left(26.7^{\circ} \mathrm{C}\right)$. Subsequently, the short resting phase started in August and coincided with the period of highest seawater temperatures $\left(27.2^{\circ} \mathrm{C}\right)$. Since $B$. brandaris has an incubation period of $\sim 2$ mo (Ramón
\& Flos 2001), intracapsular development and hatching occur during the season with warmest temperatures, a reproductive modality that certainly contributes to maximising growth and survival of the hatchlings. Similar reproductive patterns, i.e. spawning at rising seawater temperatures or cessation of oviposition at highest seawater temperatures, have been reported for several other muricids worldwide (e.g. Saglam \& Duzgunes 2007, Cudney-Bueno et al. 2008, Harding et al. 2008, Vasconcelos et al. 2008b, Saglam et al. 2009, Cumplido et al. 2010, Elhasni et al. 2010, Gharsallah et al. 2010, Lahbib et al. 2011).

Although gonadal histology is expensive and time consuming, it is also unanimously considered the most accurate means to assess reproductive state and is commonly used either to provide data for reproductive parameter estimates or to validate less costly methods of assessing gonadal development (LowerreBarbieri et al. 2011). A previous study on the reproductive cycle of Bolinus brandaris revealed a high coincidence between macro- and microscopic observations of the gonads, meaning that macroscopic maturity stages provided enough information whenever a detailed histological description was not necessary (Ramón \& Amor 2002). The present study detected a good agreement between histological analysis of the gonads and calculation of bio-physiological indices (GSI, CGI and PI). This conformity was more evident and the monthly variations were clearer in area-based indices $\left(\mathrm{GSI}_{\mathrm{A}}\right.$ and $\left.\mathrm{CGI}_{\mathrm{A}}\right)$ than in weight-based indices $\left(\mathrm{GSI}_{\mathrm{W}}\right.$ and $\left.\mathrm{CGI}_{\mathrm{W}}\right)$. In the case of the gonadosomatic indices $\left(\mathrm{GSI}_{\mathrm{W}}\right.$ and $\left.\mathrm{GSI}_{\mathrm{A}}\right)$, this might be due to the influence of the contents in the voluminous hepatopancreas of $B$. brandaris, as it is possible that some weight variation is not directly related to changes in gonadal activity (Tirado et al. 2002). For this reason, weight-based indices are less sensitive in detecting variations in the reproductive cycle and their results should be interpreted more cautiously (Vasconcelos et al. 2008c). Moreover, a minor spawning event (March to April) was not evident in gonadal histology (probably owing to the low number of individuals analysed) but was clearly detected by the area-based indices $\left(\mathrm{GSI}_{\mathrm{A}}\right.$ and $\left.\mathrm{CGI}_{\mathrm{A}}\right)$, further reinforcing their usefulness and accuracy for following the reproductive cycle of $B$. brandaris in routine analyses.

Some particular aspects of the biology of Bolinus brandaris make it vulnerable to over-exploitation. This species displays a patchy distribution in the lagoon (as evidenced by very dissimilar fishing yields between adjacent fishing gears) (Vasconcelos et al. 2008a), which may be due to local differences in 
depth, type of bottom substrata, seagrass coverage and food availability (Vasconcelos et al. 2010). Ease of capture, sedentary lifestyle, aggregation for breeding and spawning, deposition of collective spawns and intracapsular development (Ramón \& Flos 2001, Vasconcelos et al. 2008a), limit the potential of dispersal and intrinsic ability to quickly recolonise over-harvested areas. Life history characteristics of $B$. brandaris, such as relatively slow growth (Ramón \& Flos 2001, Vasconcelos et al. 2012) and first sexual maturity reached $\sim 55 \mathrm{~mm}$ SL (K. Elhasni, pers. comm.) to $65 \mathrm{~mm} \mathrm{SL}$ (Tirado et al. 2002), further increase the susceptibility of local stocks to overfishing.

This is the first study available on the reproductive cycle of an Atlantic population of Bolinus brandaris. The present study provides baseline information for potential management measures for the fishing or harvesting of this species in the Ria Formosa lagoon. In particular, establishing the timing of the spawning season is essential for preventing exploitation during this crucial phase of the reproductive cycle of $B$. brandaris. For this purpose, a closed season in the fishing activity, aimed at protecting the female broodstock and collective spawns, should be implemented during the spawning season. Preferably, this temporary prohibition of the catches should coincide with the spawning peak (June to July) of $B$. brandaris. However, the artisanal fishery targeting muricid gastropods in the Ria Formosa lagoon catches simultaneously $B$. brandaris and Hexaplex trunculus (Vasconcelos et al. 2008a); therefore, management measures should consider the reproductive biology of both species. A previous study on the reproductive cycle of $H$. trunculus led to the establishment of a closed season during the spawning peak (May and June) of this species in the Ria Formosa lagoon (Vasconcelos et al. 2008b). Accordingly, the implementation of a joint closed season in May to July, encompassing the spawning peaks of both target species, would be the ideal management measure to regulate this fishery.

Furthermore, the present study also provides useful information for assessing the potential of Bolinus brandaris as a candidate species for molluscan aquaculture. Indeed, previous pilot studies focused on establishing the technical and economical feasibility of rearing B. brandaris (e.g. Ramón \& Flos 2001, Ramón et al. 2005, Vasconcelos et al. 2012). However, despite the efforts of some researchers to achieve spawning of $B$. brandaris in captivity, this task has proved unsuccessful until now. In this context, the present study provides further insights on the most suitable timing to induce spawning of this species in captivity or to collect spawns in the field. Finally, the comparison of information obtained from the histological analyses of the gonads and from the calculation of bio-physiological indices revealed that some indices (especially the $\mathrm{GSI}_{\mathrm{A}}, \mathrm{CGI}_{\mathrm{A}}$ and $\mathrm{PI}_{\mathrm{L}}$ ) constitute a biologically meaningful alternative to gonad histology. The ability and accuracy of those indices for detecting variations in the reproductive cycle of $B$. brandaris encourage the adoption of similar approaches with other gastropod species. Particularly in routine analyses that do not require a detailed histological description, those bio-physiological indices constitute a useful and reliable alternative to timeconsuming and expensive histological analyses.

Acknowledgements. This study was partially funded by a post-doctoral grant from the Fundação para a Ciência e Tecnologia (FCT) awarded to P.V. (SFRH/BPD/26348/2006) and by the project 'Desarrollo Sostenible de las Pesquerías Artesanales del Arco Atlántico - PRESPO' (Programme INTERREG IV B, co-financed by EU, ERDF funds). Thanks are extended to P. Pousão-Ferreira (INRB, I.P./IPIMAR) for providing data on the seawater temperature and to J. Cúrdia (INRB, I.P./IPIMAR) for photographing the histological sections of the gonads. Finally, the authors acknowledge the Responsible Editor (Dr. R. Finn) and 4 anonymous referees for valuable comments and suggestions that greatly improved the revised version of the manuscript.

\section{LITERATURE CITED}

Amor MJ (1988) Algunos aspectos del aparato reproductor masculino de Murex brandaris (L., 1758) (Gastropoda, Prosobranchia). Iberus 8:51-58

Amor MJ, Durfort M (1990a) Changes in nuclear structure during eupyrene spermatogenesis in Murex brandaris. Mol Reprod Dev 25:348-356

Amor MJ, Durfort M (1990b) Atypical spermatogenesis in Murex brandaris. Mol Reprod Dev 25:357-363

Amor MJ, Ramón M, Durfort M (2004) Ultrastructural studies of oogenesis in Bolinus brandaris (Gastropoda: Muricidae). Sci Mar 68:343-353

Amor MJ, Ramón M, Durfort M (2005) Ultrastructural details of sperm degeneration in the ingestive gland of Bolinus brandaris (Gastropoda, Prosobranchia). Abstracts of the Annual Main Meeting of the Society for Experimental Biology, 11-15 July 2005, Universitat Autònoma de Barcelona, Barcelona, Spain. Comp Biochem Physiol A Mol Integr Physiol 141(Suppl):S208 (Abstract)

Amor MJ, Ramón M, Durfort M (2007) Aspectos morfológicos y ultraestructurales de la glándula de la cápsula de Bolinus brandaris (Gastropoda, Prosobranchia). Boll Malacol 43:78-86

Anonymous (2001) Especies de interés pesquero en el litoral de Andalucía. II. Invertebrados. Junta de Andalucía, Consejería de Agricultura y Pesca, Sevilla

Barash A, Zenziper Z (1980) Egg masses of Mollusca from Mediterranean waters of Israel and notes on reproduction of the freshwater species Theodoxus jordani and 
Melanoides tuberculata. Veliger 22:299-317

Bartolome C (1985) Contribution à l'étude du gastéropode Murex brandaris (Linnaeus, 1758) dans le Golfe du Lion. Diplôme d'Etudes Approfondies de Sciences de l'Eau et Aménagement, Académie de Montpellier, Université des Sciences et Techniques du Languedoc

Càceres C, Giménez-Bonafé P, Ribes E, Wouters-Tyrou D and others (1999) DNA-interacting proteins in the spermiogenesis of the mollusc Murex brandaris. J Biol Chem 274:649-656

Cecalupo A, Vianello M, Perini L (2006) Alcune forme aberranti rinvenute nel Mare Adriatico di Hexaplex trunculus (Linnaeus, 1758) e Bolinus brandaris (Linnaeus, 1758). Not SIM Pubbl Soc Ital Malacol 24:13-15

Cudney-Bueno R, Prescott R, Hinojosa-Huerta O (2008) The black murex snail, Hexaplex nigritus (Mollusca, Muricidae), in the Gulf of California, Mexico: I. Reproductive ecology and breeding aggregations. Bull Mar Sci 83: 285-298

> Cumplido M, Averbuj A, Bigatti G (2010) Reproductive seasonality and oviposition induction in Trophon geversianus (Gastropoda: Muricidae) from Golfo Nuevo, Argentina. J Shellfish Res 29:423-428

D'Asaro CN (1991) Gunnar Thorson's world-wide collection of prosobranch egg capsules: Muricidae. Ophelia 35: $1-101$

> Defeo O, Castilla JC (2005) More than one bag for the world fishery crisis and keys for co-management successes in selected artisanal Latin American shellfisheries. Rev Fish Biol Fish 15:265-283

Elhasni K, Ghorbel M, Vasconcelos P, Jarboui O (2010) Reproductive cycle and size at first sexual maturity of Hexaplex trunculus (Gastropoda: Muricidae) in the Gulf of Gabès (southern Tunisia). Invertebr Reprod Dev 54: 213-225

FAO (Food and Agriculture Organization of the United Nations) (2011) FAO yearbook 2009: fishery and aquaculture statistics. FAO, Rome

Fretter V, Graham A (1994) British prosobranch molluscs: their functional anatomy and ecology. The Ray Society, London

Gharsallah IH, Vasconcelos P, Zamouri-Langar N, Missaoui H (2010) Reproductive cycle and biochemical composition of Hexaplex trunculus (Gastropoda: Muricidae) from Bizerte lagoon, northern Tunisia. Aquat Biol 10:155-166

> Harding JM, Mann R, Kilduff CW (2008) Influence of environmental factors and female size on reproductive output in an invasive temperate marine gastropod Rapana venosa (Muricidae). Mar Biol 155:571-581

> Himmelman JH, Hamel JR (1993) Diet, behaviour and reproduction of the whelk Buccinum undatum in the northern Gulf of St. Lawrence, eastern Canada. Mar Biol 116:423-430

Hotchkiss AK, Sternberg RM, LeBlanc GA (2008) Environmental cues trigger seasonal regression of primary and accessory sex organs of the mud snail, Ilyanassa obsoleta. J Molluscan Stud 74:301-303

Houart R (2001) A review of the recent Mediterranean and Northeastern Atlantic species of Muricidae. Evolver, Rome

- Ilano AS, Fujinaga K, Nakao S (2003) Reproductive cycle and size at sexual maturity of the commercial whelk Buccinum isaotakii in Funka Bay, Hokkaido, Japan. J Mar Biol Assoc UK 83:1287-1294

Katsanevakis S, Poursanidis D, Issaris Y, Panou A and others (2011) 'Protected' marine shelled molluscs: thriving in
Greek seafood restaurants. Mediterr Mar Sci 12:429-438 > Lahbib Y, Abidli S, Trigui El Menif N (2011) Spawning and intracapsular development of Stramonita haemastoma haemastoma (Gastropoda: Muricidae) collected in northern Tunisia. Mar Biol Res 7:719-726

Leiva GE, Castilla JC (2002) A review of the world marine gastropod fishery: evolution of the catches, management and the Chilean experience. Rev Fish Biol Fish 11:283-300

Lowerre-Barbieri SK, Brown-Peterson NJ, Murua H, Tomkiewicz J, Wyanski DM, Saborido-Rey F (2011) Emerging issues and methodological advances in fisheries reproductive biology. Mar Coast Fish Dynam Manag Ecosyst Sci 3:32-51

Mallol S, Muñoz M, Hernández MR, Casadevall M (2004) Evaluation of the purple dye murex Bolinus brandaris (Mollusca: Gastropoda) population as a new fishery resource in the Gulf of Roses (Catalan coast, NW Mediterranean). Rap Comm Int Mer Méditerr 37:394-395

> Martel A, Larrivée DH, Himmelman JH (1986a) Behaviour and timing of copulation and egg-laying in the neogastropod Buccinum undatum L. J Exp Mar Biol Ecol 96: $27-42$

> Martel A, Larrivée DH, Klein KR, Himmelman JH (1986b) Reproductive cycle and seasonal feeding activity of the neogastropod Buccinum undatum. Mar Biol 92:211-221

- Martín P, Sánchez P, Ramón M (1995) Population structure and exploitation of Bolinus brandaris (Mollusca: Gastropoda) off the Catalan coast (northwestern Mediterranean). Fish Res 23:319-331

Poppe GT, Goto Y (1991) European seashells, Vol 1 (Polyplacophora, Caudofoveata, Solenogastra, Gastropoda). Verlag Christa Hemmen, Wiesbaden

> Ramón M, Amor MJ (2001) Increasing imposex in populations of Bolinus brandaris (Gastropoda: Muricidae) in the north-western Mediterranean. Mar Environ Res 52: 463-475

Ramón M, Amor MJ (2002) Reproductive cycle of Bolinus brandaris and penis and genital duct size variations in a population affected by imposex. J Mar Biol Assoc UK 82: 435-442

Ramón M, Flos R (2001) First trials to cultivate the muricid gastropod Bolinus brandaris (Linnaeus). Eur Aquac Soc Spec Publ 29:219-220

Ramón M, Cano J, Peña JB, Campos MJ (2005) Current status and perspectives of mollusc (bivalves and gastropods) culture in the Spanish Mediterranean. Bol Inst Esp Oceanogr 21:361-373

> Saglam H, Duzgunes E (2007) Deposition of egg capsule and larval development of Rapana venosa (Gastropoda: Muricidae) from the south-eastern Black Sea. J Mar Biol Assoc UK 87:953-957

Saglam H, Duzgunes E, Ogut H (2009) Reproductive ecology of the invasive whelk Rapana venosa Valenciennes, 1846, in the southeastern Black Sea (Gastropoda: Muricidae). ICES J Mar Sci 66:1865-1867

Spanier E, Karmon N (1987) Muricid snails and the ancient dye industries. In: Spanier E (ed) The royal purple and the biblical blue: argaman and tekhelet. Keter Publishing House, Jerusalem, p 179-192

- Sternberg RM, Gooding MP, Hotchkiss AK, Leblanc GA (2010) Environmental-endocrine control of reproductive maturation in gastropods: implications for the mechanism of tributyltin-induced imposex in prosobranchs. Ecotoxicology 19:4-23

Swanson CA (2004) Effect of substrate availability and 
conspecific cues on communal oviposition in the apple murex snail Phyllonotus pomum. Mar Ecol Prog Ser 275: 175-184

Tirado C, Rodríguez de la Rúa A, Bruzón MA, López JI, Salas C, Márquez I (2002) La reproducción de bivalvos y gasterópodos de interés pesquero en Andalucía. Junta de Andalucía, Consejería de Agricultura y Pesca, Huelva

- Vasconcelos P, Carvalho S, Castro M, Gaspar MB (2008a) The artisanal fishery for muricid gastropods (banded murex and purple dye murex) in the Ria Formosa lagoon (Algarve coast, southern Portugal). Sci Mar 72:287-298

Vasconcelos P, Lopes B, Castro M, Gaspar MB (2008b) Gametogenic cycle of Hexaplex (Trunculariopsis) trunculus (Gastropoda: Muricidae) in the Ria Formosa lagoon (Algarve coast, southern Portugal). J Mar Biol Assoc UK 82:321-329

- Vasconcelos P, Lopes B, Castro M, Gaspar MB (2008c) Comparison of indices for the assessment of reproductive activity in Hexaplex trunculus (Gastropoda: Muricidae).

Editorial responsibility: Roderick Finn,

Bergen, Norway
Mar Biol Res 4:392-399

Vasconcelos P, Gaspar MB, Barroso CM (2010) Imposex in Bolinus brandaris from the Ria Formosa lagoon (southern Portugal): usefulness of 'single-site baselines' for environmental monitoring. J Environ Monit 12:1823-1832

Vasconcelos P, Moura P, Barroso CM, Gaspar MB (2011) Size matters: importance of penis length variation on reproduction studies and imposex monitoring in Bolinus brandaris (Gastropoda: Muricidae). Hydrobiologia 661: 363-375

Vasconcelos P, Pereira AM, Constantino R, Barroso CM, Gaspar MB (2012) Growth of the purple dye murex, Bolinus brandaris (Gastropoda: Muricidae), marked and released in a semi-intensive fish culture earthen pond. Sci Mar 76:67-78

Wayne NL (2001) Regulation of seasonal reproduction in mollusks. J Biol Rhythms 16:391-402

Zar JH (1999) Biostatistical analysis, 4th edn. Prentice Hall, Upper Saddle River, NJ

Submitted: October 5, 2011; Accepted: March 28, 2012 Proofs received from author(s): May 27, 2012 